\title{
Os governos de Lula da Silva e os IMPASSES À PARTICIPAÇÃO NO BRASIL
}

\author{
Kátia Alves FUKUSHIMA* \\ Maria do Socorro Sousa BRAGA*
}

\begin{abstract}
RESUMO: O objetivo deste artigo é verificar como a correlação de forças e a assimetria de recursos políticos impactaram no processo de implementação de mecanismos de participação nos governos de Lula da Silva (2003-2010). Para tanto, realizamos um estudo de caso com foco em duas dimensões: a) correlação de forças políticas e econômicas - com a oposição partidária e setores empresariais e b) recursos políticos - oriundos dos legados institucionais, do sistema político, dos pactos e da base de apoio social. Concluímos que apesar dos impasses institucionais e da correlação de forças políticas ideologicamente heterogênea houve avanços em relação à participação política e ao acesso a bens sociais de setores até então marginalizados.
\end{abstract}

PALAVRAS-CHAVE: Participação. Governo Lula da Silva. Democracia Liberal. Conciliação entre classes.

\section{Introdução ${ }^{1}$}

O governo Lula (2003-2010) se insere na chamada maré rosa ou giro à esquerda que ocorreu na primeira década do século XXI, quando líderes e/ou partidos

\footnotetext{
UFES - Universidade Federal do Espírito Santo. Bolsista (PROFIX-D) FAPES/CAPES. Vitória - ES Brasil. 29075-910 - kafukushima.politica@gmail.com - https://orcid.org/0000-0001-7588-9228.

* UFSCar - Universidade Federal de São Carlos. São Carlos - SP - Brasil. 13565-905 - msbraga@ ufscar.br. https://orcid.org/0000-0003-2141-9778.

1 Este artigo é parte dos projetos de investigação "Avaliando a qualidade da democracia em países da América Latina (II)", apoiado com uma bolsa de produtividade do Conselho Nacional de Desenvolvimento 
de esquerda e centro-esquerda ascenderam ao Poder Executivo em vários países da América Latina ${ }^{2}$. A literatura especializada atribuiu a origem desse fenômeno político a vários fatores, tais como, a implementação de políticas neoliberais por parte dos governos anteriores, as crises econômicas e políticas e a insatisfação da população com os partidos tradicionais. Para os objetivos desta análise outros dois fatores indicados são cruciais: o primeiro se refere ao processo de acumulação que a esquerda adquiriu com as experiências em governos municipais e estaduais; e, o segundo, diz respeito ao déficit de representação e participação, principalmente, das chamadas minorias sociais dessas sociedades (PANIZZA, 2006; CLEARY, 2006).

Embora esses governos tenham ascendido ao poder dentro das regras do jogo da democracia liberal, e na economia muitos mantiveram a adoção de políticas neoliberais, eles assumiram papel crucial na região ao defenderem mudanças visando uma ordem democrática mais inclusiva, participativa e menos desigual. A ascensão do Partido dos Trabalhadores (PT) e do sindicalista - Lula da Silva (doravante Lula) - ao poder Executivo representou a possibilidade desse aprofundamento da democracia brasileira. A história social do PT e as experiências das administrações petistas em algumas cidades, com o Orçamento Participativo $(\mathrm{OP})^{3}$, indicavam esse caminho.

O programa de governo de Lula enfatizava propostas de inclusão social e de combate à desigualdade, à fome e ao clientelismo, "convertendo o social no eixo do novo modelo de desenvolvimento", priorizando "o crescimento do emprego; a geração e distribuição de renda e a ampliação da infraestrutura social". Ademais, propunha "criar uma alternativa econômica para enfrentar e vencer o desafio histórico da exclusão social [a qual] exige a presença ativa e a ação reguladora do Estado sobre o mercado, evitando o comportamento predatório de monopólios e oligopólios" (COLIGAÇÃO LULA PRESIDENTE, 2002, p.3-30).

A partir deste cenário e da proposta do governo Lula, nosso objetivo consiste em analisar como a correlação de forças políticas e a assimetria de recursos políticos impactaram a gestão de Lula (2003-2010) no processo de implementação de mecanismos de participação. Nosso argumento parte do pressuposto de que a vontade política nem sempre se materializa em ação e resultado político almejados.

\footnotetext{
Científico e Tecnológico (CNPq) e "Políticas sociais e democracia: uma análise dos governos Nicolás Maduro (2013-2018) e Dilma Rousseff (2010-2016)" desenvolvido na Universidade Federal do Espírito Santo, com financiamento FAPES/CAPES, bem como, parte dos resultados da tese de doutorado intitulada "A tensão entre democracia e participação nos governos de esquerda: os casos do Brasil, Chile e Venezuela" desenvolvida na Universidade Federal de São Carlos com financiamento do CNPq. 2 Venezuela (Hugo Chávez, 1998); Argentina (Néstor Kirchner, 2003); Uruguai (Tabaré Vázquez, 2004); Bolívia (Evo Morales, 2005); Chile (Michele Bachelet, 2006); Equador (Rafael Correa, 2006), Nicarágua (Daniel Ortega, 2006); Paraguai (Fernando Lugo, 2008) e El Salvador (Mauricio Funes, 2009).

3 O OP é uma política que permite aos cidadãos influenciar e/ou decidir através de sua participação nas assembleias e nos processos de negociação com o governo, sobre como gastar o orçamento público destinado a novos investimentos.
} 
Isto porque os recursos políticos e a correlação de forças em um governo geram diferentes oportunidades no processo decisório.

A base teórica deste artigo está assentada na teoria de democracia participativa de Macpherson (1978, p.103). Esta é entendida como o aperfeiçoamento da democracia liberal, que pressupõe o "afastamento do homem como consumidor maximizante, e grande redução da atual desigualdade econômica e social". Contudo, o autor reconhece que para que isto ocorra é necessária uma participação democrática muito maior do que a que está presente nas democracias liberais existentes. Logo, a solução seria criar políticas que busquem reduzir as desigualdades e estimulem a participação. Esta teoria nos ajuda a pensar a administração de Lula e sua proposta de governo de aperfeiçoar a democracia brasileira através da participação e inclusão. Resta saber, se seu governo, diante dos recursos políticos e da correlação de forças políticas do país, conseguiu de fato aprofundar a democracia.

Para analisar essa questão, metodologicamente realizamos um estudo de caso com foco em duas dimensões: a) correlação de forças políticas e econômicas - com a oposição partidária e setores empresariais e b) recursos políticos - oriundos dos legados institucionais, do sistema político, dos pactos e da base de apoio social. $\mathrm{O}$ processo de implementação de mecanismos participativos e de aprofundamento da democracia foi analisado a partir de dois eixos analíticos: i) mecanismos de participação e inclusão e ii) condições favoráveis à participação.

$\mathrm{O}$ artigo está dividido em quatro seções, incluindo esta introdução. $\mathrm{Na}$ segunda seção, verificamos quais os recursos políticos institucionais e sociais que o governo Lula contou para implementar sua agenda participacionista. Identificamos como estava a configuração da correlação de forças políticas e os constrangimentos que impactaram no processo de implementação da agenda governamental. Na terceira seção, avaliamos a efetividade da administração petista nessa dimensão, seja indicando os mecanismos de participação e inclusão criados, seja efetivando políticas sociais de acesso à educação e de redução da pobreza e das desigualdades. Em seguida, tecemos as considerações finais.

\section{Governos Lula da Silva (2003-2010): dilemas de conciliação de classes}

Para compreendermos os impasses que o governo petista enfrentou ao buscar implementar sua agenda social e de ampliação da participação cidadã temos que analisar ao menos duas dimensões de uma democracia liberal. A primeira se refere à correlação de forças político-sociais representada no Executivo e no Legislativo. Em outras palavras, precisamos verificar como estava distribuído o poder político entre as forças relevantes do país e como se deram as relações do governo com a 
oposição, com os partidos da coalizão governamental e parlamentar e com setores internos ao próprio partido do presidente. De acordo com Linz (1991, p.45), "além de responder às demandas de um amplo eleitorado e dos membros do partido, os governos democráticos não podem ignorar as dos grupos de interesses”. Já Easton (1968, p.185) enfatiza que muitas vezes no processo decisório é preciso calcular o custo e o benefício que determinada decisão irá gerar. Pois, quando setores chaves, como os setores econômicos, perdem a confiança no governo, "podem ser mais decisivos que o apoio do eleitorado". Neste sentido, ensina que "a pressão que se produz entre os diversos interesses, sobre o conteúdo da política prática, pode ser descrita como um 'estica e afrouxa entre os grupos' para o controle do aparato governamental".

A segunda dimensão diz respeito aos recursos políticos que governos democráticos poderão contar em cada sociedade. Esses recursos podem ser de cinco tipos. O primeiro se refere às características estruturais da sociedade, que ofereceriam uma série de oportunidades e obstáculos para os atores sociais e políticos, podendo levar a um ou outro resultado (LINZ, 1991. O segundo está relacionado à configuração dos sistemas políticos nos quais os governos têm que atuar, especialmente no formato do sistema partidário e no tipo de sistema eleitoral adotado para transformar votos em poder político. As principais implicações do desenho institucional podem gerar distorções entre o voto da população e a representação no governo, o distanciamento entre representantes e representados, bem como, pode implicar na formação de amplas coalizões ideológicas entre os partidos, o que por sua vez, suscita a negociação de interesses distintos, limitando a agenda de governo. Já o terceiro, foca nos recursos vinculados aos legados institucionais, que determinariam os recursos institucionais e de poder deixados por governos e/ou regimes anteriores e que influenciariam no processo decisório. O quarto, seriam os pactos estabelecidos pelos atores políticos e, por fim, o quinto recurso, conformar-se-ia pelas bases sociais com as quais tais governos poderiam contar (LINZ, 1991; EASTON, 1968).

O Brasil chegou ao século XXI com uma democracia relativamente estável no que se refere aos procedimentos que regulam a competição política, à alternância de grupos políticos no controle do poder político nas esferas municipal, estadual e nacional, à configuração de um sistema partidário inclusivo e, à ampliação da cidadania eleitoral. Mas, ao mesmo tempo, apresenta déficits de representatividade de segmentos populacionais socialmente minoritários. Ademais, o país não conseguiu avançar o suficiente para democratizar o acesso da maioria da sociedade às políticas de bem-estar social, aprofundando a desigualdade na distribuição da renda, da educação e saúde de qualidade, alargando, assim, as barreiras entre as classes sociais. Essa assimetria entre as dimensões do sistema democrático brasileiro 
vem gerando muitas contradições no seu funcionamento, afetando, assim, o desenvolvimento do grau de amplitude de sua legitimidade.

Foi nesse contexto, após 113 anos da Proclamação da República brasileira, que o sindicalista e ex-deputado federal Luiz Inácio Lula da Silva (PT) foi eleito presidente no pleito de 2002, no segundo turno, com quase 53 milhões de votos, $61,27 \%$ contra $38,73 \%$ obtidos pelo ex-senador José Serra (PSDB) (BRASIL, 2003). Para realizar esse feito o esquerdista Partido dos Trabalhadores se coligou com partidos do mesmo espectro político ideológico (PCdoB, PCB, PMN) e com o Partido Liberal (PL) de centro-direita, visando justamente ampliar suas chances de apoio no eleitorado moderado e adepto do receituário liberal no que se refere à economia. Esse movimento do PT no sentido de uma política de aliança entre classes políticas para que houvesse margem para a governabilidade foi materializado em outros momentos da campanha como, por exemplo, o lançamento da Carta aos Brasileiros em junho daquele ano, publicada em vários jornais do país. Nessa carta o candidato presidencial Lula afirmava:

Há outro caminho possível. É o caminho do crescimento econômico com estabilidade e responsabilidade social. As mudanças que forem necessárias serão feitas democraticamente, dentro dos marcos institucionais. Vamos ordenar as contas públicas e mantê-las sob controle. Mas, acima de tudo, vamos fazer um compromisso pela produção, pelo emprego e por justiça social (FOLHA, 2002, n.p.).

Em resposta a esses apelos em meio a forte crise econômica e alta taxa de desemprego, o eleitorado nacional, mas especialmente o da região Sudeste $(51,62 \%)$, economicamente mais ativo do país, votou majoritariamente na proposta socialdemocrata dos petistas.

Mas se o ex-presidente Lula chegou à presidência da República com alta popularidade, o mesmo não ocorreu com os partidos que formariam sua base parlamentar inicial. Conforme tabela 1, no primeiro ano de governo o ex-presidente contava com uma base (PT, PSB, PDT, PV, PTB, PCdoB, PL e PPS) controlando 49,3\% das cadeiras da Câmara. Mesmo a bancada do PT nesta Casa, embora fosse a maior daquela Legislatura, chegou a apenas $18 \%$. Já a oposição (PFL/DEM; PSDB; PRONA) contava com $26 \%$ das cadeiras. No Senado o PT elegeu a segunda bancada, ficando com $12 \%$ das cadeiras. Mas sua base parlamentar (PT, PL, PDT, PTB, PSB, PPS) era ainda menos expressiva (28,4\%). Em contrapartida a oposição controlava ampla maioria, agregando $71,6 \%$ das cadeiras. 
Tabela1: Correlação de Forças Políticas no Primeiro Governo Lula (2003)

\begin{tabular}{l|c|c|c|c|c}
\hline & $\begin{array}{c}\text { Base do } \\
\text { governo }\end{array}$ & Oposição & \multicolumn{3}{|c}{ \% Ministério } \\
\hline $\begin{array}{l}\text { Câmara dos } \\
\text { Deputados }\end{array}$ & $49,3^{1}$ & $26,0^{2}$ & \multicolumn{2}{|c}{ Partido } & Sem partido \\
\hline \multirow{2}{*}{ Senado } & 28,4 & 71,6 & PT & Base aliada & 13,7 \\
\cline { 4 - 5 } & & & 54,8 & 31,5 & \\
\hline
\end{tabular}

Nota 1: Coalizão entre jan. 2003 a jan. 2004 composta pelos partidos: PT, PSB, PDT, PPS, PCdoB, PV, PL e PTB.

Nota 2: PFL/DEM; PSDB; PRONA.

Fonte: Elaboração das autoras a partir de dados do TSE (BRASIL, 2003) e dos estudos de Palotti e Cavalcante (2019); Amorim Neto (2007); Freitas (2016).

Diante desse cenário, para ampliar sua margem de negociação política e conseguir aprovar as reformas constitucionais, o PT teve que atrair mais partidos para sua base parlamentar. Esse foi o caso do PMDB, PP e PSC, acrescentando mais 133 deputados nos anos seguintes. Desse modo dos 15 partidos representados na Câmara a partir de 2003, 11 passaram a apoiar o governo, reunindo uma base parlamentar com 376 deputados, ou cerca de $73 \%$ da Casa ${ }^{4}$. No Senado, a base de apoio ao ex-presidente Lula passou a contar com sete partidos, chegando a 53 senadores $(65,4 \%)$. Parte desse aumento se deve também ao crescimento das legendas da base aliada no primeiro ano de alta popularidade do ex-presidente Lula, quando normalmente ocorre a primeira onda de mudanças partidárias em decorrência do resultado do pleito majoritário. Muitos deputados procuraram realinhar-se à nova correlação de forças políticas, tendo como centro de gravidade os campos do governo e da oposiçãos.

Ainda sobre a correlação de forças é importante ressaltarmos que os números da base parlamentar, devido ao seu perfil idelogicamente mais amplo, devem ser tomados com cautela quanto ao grau de governabilidade do presidente. Isso porque, dependendo dos interesses econômicos e sociais contraditórios envolvidos na matéria, as bancadas dificilmente votarão fechadas. Foi por isso que as negociações foram pontuais e recomeçaram a cada novo projeto submetido à votação. Foi assim,

\footnotetext{
4 O PDT em 2004 rompeu com o governo petista, que perdeu os 13 deputados, embora o ministro das Comunicações, Miro Teixeira, nomeado na cota do partido no Executivo, permaneceu no cargo.

5 Como o PTB (passou de 41 para 52 deputados), o PL (de 34 para 43) e o PSC (de 1 passou a 7 deputados). Enquanto, as legendas de oposição sofreram perdas: o PFL caiu de 76 para 68 deputados; o PSDB, de 63 para 50; o PDT, de 18 para 13; e o Prona, de 6 para 2, PMN perdeu seus 2 deputados, ficando sem representantes.
} 
por exemplo, na votação das reformas Tributária ${ }^{6}$ e da Previdência. Como envolvia temas polêmicos, foram necessárias muitas negociações e concessões por parte do governo Lula para garantir o apoio da base. Outro exemplo, foi quando Lula propôs a emenda, PEC n89 de 2007, para prorrogação da Contribuição Provisória sobre Movimentação Financeira ${ }^{7}$ (CPMF) por mais quatro anos - até 2011. A base aliada do governo era de $76 \%$ na Câmara e tinha a maioria dos votos nominais no Senado, mas essa maioria no Congresso não se refletiu em vitória. De acordo com Navarro e Cabral (2007), foram sete "traições" na base que selaram a derrota da emenda da CPMF. Essa situação demonstrou um governo cada vez mais dependente do PMDB, partido que então possuía a maior bancada com 20 senadores.

Outra dimensão relevante na análise dos impasses enfrentados pelo governo petista diz respeito à distribuição dos ministérios entre os partidos da coalizão governamental mais heterogênea ideologicamente. Conforme a tabela 1, no primeiro mandato, o PT concentrou quase 55\% dos ministérios, enquanto os partidos da coalizão governamental agregaram apenas $31,5 \%$ e, quase $14 \%$ estavam com ministros sem filiação partidária. A estratégia desse governo foi a expansão de uma estrutura ministerial que permitisse garantir ao partido do presidente o domínio sobre os setores social e de governo, considerando o número de ministérios ocupados pelo PT. Na análise por partidos, destaca-se a presença do PMDB em todos os governos petistas, mais concentradamente em pastas do setor de infraestrutura. Consequentemente, nos oito anos do governo, a negociação com os partidos se alinhou mais à centro-direita, oferecendo cargos no primeiro e segundo escalões e, assim, o governo Lula formou sua base aliada.

O reflexo dessas coalizões pode ser visto na composição dos partidos por ministérios (tabela 2). Durante o governo Lula, esse arranjo multipartidário conferiu aos ministérios um número significativo de partidos, tendo em 2005, nove partidos no primeiro escalão do governo. Segundo Amorim Neto (2007, p.132), o governo constituiu o "mais fragmentado ministério formado na história do presidencialismo latino-americano".

\footnotetext{
6 Na tentativa de aprovar a reforma tributária, o ex-presidente Lula não conseguiu a adesão da maioria dos deputados. Com isso, fatiou a proposta e aprovou apenas pontos da matéria, como o que aumentou em $1 \%$ o Fundo de Participação dos Municípios, levando o repasse de $22,5 \%$ para $23,5 \%$.

7 A CPMF estabelecia uma alíquota de $0,38 \%$ sobre movimentações financeiras e arrecadava aproximadamente $1,4 \%$ do PIB para o governo federal.
} 
Tabela 2: Base Governista e apoio na Câmara dos Deputados (2003-2007) - Brasil

\begin{tabular}{cccc}
\hline $\begin{array}{c}\text { Período de } \\
\text { Duração }\end{array}$ & $\begin{array}{c}\text { Coligações de Governo/Partidos } \\
\text { Representados nos Ministérios }\end{array}$ & $\begin{array}{c}\text { Apoio na Câmara } \\
\text { (nominal) (\%) }\end{array}$ \\
\hline $01 / 03-01 / 04$ & PT/PSB/PDT/PPS/PCdoB/PV/PL/PTB & 49,3 \\
& $01 / 04-07 / 05$ & PT/PSB/PPS/PCdoB/PV/PL/PTB/PMDB & 62 \\
Governo & $06 / 05-08 / 05$ & $\mathrm{PT} / \mathrm{PSB} / \mathrm{PCdoB} / \mathrm{PV} / \mathrm{PL} / \mathrm{PTB} / \mathrm{PMDB}$ & 59,8 \\
Lula & $08 / 05-09 / 05$ & $\mathrm{PT} / \mathrm{PSB} / \mathrm{PCdoB} / \mathrm{PV} / \mathrm{PL} / \mathrm{PTB} / \mathrm{PMDB}$ & 69 \\
& $09 / 05-04 / 06$ & $\mathrm{PT} / \mathrm{PSB} / \mathrm{PCdoB} / \mathrm{PV} / \mathrm{PTB} / \mathrm{PMDB} / \mathrm{PP} / \mathrm{PRB} / \mathrm{PL}$ & 69 \\
& $04 / 06-12 / 06$ & $\mathrm{PT} / \mathrm{PSB} / \mathrm{PCdoB} / \mathrm{PV} / \mathrm{PTB} / \mathrm{PMDB} / \mathrm{PP}$ & 58,4 \\
& Dez. $/ 2007$ & $\mathrm{PMDB} / \mathrm{PDT} / \mathrm{PSB} / \mathrm{PCdoB} / \mathrm{PR} / \mathrm{PP} / \mathrm{PTB}$ & 76,2 \\
\hline
\end{tabular}

Fonte: Elaboração das autoras a partir de Amorim Neto (2007, p.134); IPEA (2010, p.131); Navarro e Cabral (2007).

O fato é que a governabilidade no Brasil, "tem se estruturado a partir dos laços entre os Poderes Legislativo e Executivo, por meio da formação de maiorias parlamentares, à luz do presidencialismo de coalizão" (IPEA, 2010, p.129). Como aponta Abranches (2018, p.69-70), essas "coalizões não são eventuais, elas são imperativas. Nenhum presidente governou sem o apoio e o respeito de uma coalizão". Contudo, a "associação entre a dependência da governança ao apoio parlamentar e a correlação entre sucesso eleitoral dos parlamentares e acesso a recursos e cargos governamentais gera poderosos incentivos ao toma-lá-dá-cá, ao clientelismo e à patronagem" (ABRANCHES, 2018, p.79), o que por sua vez, pode gerar impasses no processo decisório.

Vale lembrar que o governo em seus primeiros anos enfrentou algumas crises internas, quando optou por uma equipe econômica conservadora e tomou medidas, como a adoção de uma reforma regressiva da previdência, que gerou desavenças entre o governo e setores dos movimentos sociais e do próprio PT contrários a tal reforma e às políticas econômicas conservadoras (SADER, 2013). Diante desse processo, o PT perdeu alguns setores que passaram a ser críticos incondicionais ao governo. Este ainda enfrentou tensões com o Movimento dos Trabalhadores Rurais Sem Terra (MST) e as organizações de trabalhadores do campo. Contudo, "no fim de 2003, o presidente reuniu-se com as lideranças do MST, da Confederação Nacional dos Trabalhadores na Agricultura (Contag) e da Pastoral da Terra, para pedir lealdade. Que só o julgassem no final do mandato" (Abranches, 2018, p.238). A busca para conciliar os diversos interesses se tornou explícita no processo de acalmar os movimentos sociais.

Em 2006, Lula foi reeleito com $60,83 \%$ dos votos, no $2^{\circ}$ turno, mantendo em alta sua popularidade. Nessas eleições a base eleitoral do PT se concentrou, 
principalmente, nas regiões norte e nordeste. Os problemas enfrentados no primeiro governo petista, culminando com os escândalos do mensalão ${ }^{8}$ em 2005, levaram a importantes mudanças na coalizão governamental no segundo mandato. A mais significativa foi a reforma ministerial que possibilitou maior equilíbrio entre os nove partidos na distribuição dos ministérios. De acordo com informações da tabela 3, enquanto o PT passou a controlar $42,3 \%$ dos ministérios, os demais partidos da base somaram quase $37 \%$. O PMDB foi o grande beneficiado, conquistando cinco ministérios estratégicos, cujos orçamentos equivaliam a $48 \%$ dos recursos de investimento da União para 2007.

Tabela 3: Correlação de Forças Políticas no Segundo Governo Lula da Silva (2007*)

\begin{tabular}{l|c|c|c|c|c}
\hline & Base do governo & Oposição & \multicolumn{3}{|c}{ \% Ministério } \\
\hline $\begin{array}{l}\text { Câmara dos } \\
\text { Deputados }\end{array}$ & 76,2 & 24,2 & \multicolumn{2}{|c|}{ Partido } & \multirow{2}{*}{ Sem partido } \\
\hline Senado & 58 & 42 & PT & Base aliada & \multirow{2}{*}{21,1} \\
\cline { 4 - 5 } & & & 42,3 & 36,6 & \\
\hline
\end{tabular}

Fonte: Elaboração das autoras a partir de dados do TSE (BRASIL, 2003); Palotti e Cavalcante, 2019; Amorim Neto, 2007; Navarro e Cabral, 2007; Freitas, 2016.

No que diz respeito à formação da base parlamentar, o segundo governo de Lula contou com o apoio de nove partidos (PT, PSB, PDT, PCdoB, PMDB, PL, PTB, PR e PP), controlando $76 \%$ dos votos da Câmara dos Deputados e $58 \%$ dos votos do Senado, garantindo maiorias necessárias para governar. Mas formar maiorias com partidos representativos de grupos de interesse muito heterogêneos ideologicamente tem um custo alto para governar e administrar conflitos sociais inconciliáveis. As bancadas dos ruralistas e dos evangélicos, por exemplo, demonstraram poder de pressão no governo através das frentes parlamentares ${ }^{9}$ que chegaram a 84 entre 2007 e 2011, limitando a implementação de várias políticas sociais (GONÇALVES, 2009).

Apesar da pressão, o Congresso Nacional aprovou mais medidas provisórias (MP) de iniciativa do governo do que propostas apresentadas pelos parlamentares. Como o instrumento da MP é mais rápido do que os projetos de lei, Lula usou desse mecanismo e conseguiu a aprovação da grande maioria delas.

No seu segundo mandato, Lula buscou gerenciar as crises ligadas aos casos de corrupção e em uma situação econômica favorável, "abandonou a orientação con-

8 O chamado escândalo do Mensalão tratou-se de denúncias contra diversos deputados, autoridades e integrantes do governo acusados de receberem dinheiro para favorecerem empresas em licitações, órgãos federais e votações no Congresso.

9 Associações suprapartidárias previstas legalmente no regimento do Senado e da Câmara dos Deputados (GONÇALVES, 2009). 
servadora da política econômica, substituindo-a por um modelo de desenvolvimento que articulava estruturalmente crescimento econômico com políticas de distribuição de renda" (SADER, 2013, p.141). As principais medidas foram o Programa de Aceleração do Crescimento (PAC), lançado em 2007, e a política de valorização do salário-mínimo ${ }^{10}$, criada entre 2006 e 2008. Segundo Barbosa (2013, p.79), essa política "foi resultado de uma negociação entre governo e centrais sindicais e teve como objetivo principal promover o crescimento real mais rápido do salário-mínimo caso a economia tivesse um bom desempenho". Diante do cenário econômico, o segundo governo petista conseguiu continuar com suas negociações relativamente equilibradas com os sindicatos operários, que "mantiveram-se em relativa tranquilidade, recorrendo raramente a greves" (CARVALHO, 2014, p.232).

A política de "conciliação de diversos interesses de classes" teve consequências substantivas para a realização de reformas estruturais tão necessárias ao avanço da democratização das áreas sociais, comunicação, tributárias e participacionistas. Isso porque se, por um lado, buscou-se ampliar o apoio do poder econômico especialmente no Congresso, mas também no financiamento privado das campanhas eleitorais, aumentando ainda mais a influência do empresariado na formulação das políticas públicas. Por outro lado, a boa relação do ex-presidente Lula com os movimentas sociais possibilitou um apaziguamento dos mesmos durante seu governo. Lula tinha grande legitimidade perante a população haja visto suas altas votações eleitorais. Mas muito desse apoio foi devido ao aumento do poder de compra que a população adquiriu durante o seu governo. A política de incentivo ao consumo, particularmente dos setores populares, foi um dos aspectos mais visíveis da materialização da política de conciliação de classes sociais do governo petista.

Ainda que o governo Lula tenha apresentado avanços significativos, em especial, na área social, como veremos na seção seguinte, é importante destacar que as pressões políticas de bancadas no Congresso, como a dos ruralistas e/ou de setores conservadores, impuseram limites à agenda participacionista do governo. Diante de tais pressões e buscando preservar uma governabilidade estável, a legitimidade adquirida perante a população e a boa relação com os movimentos sociais não foram utilizadas para pressionar o Congresso no sentido de promover reformas estruturais tão necessárias para o avanço da democracia brasileira.

\footnotetext{
${ }^{10}$ Esta política "estabelecia reajustes anuais de acordo com a inflação, com defasagem de um ano, e o crescimento do PIB da economia, com defasagem de dois anos" (BARBOSA, 2013, p.79).
} 


\section{Adimensão da Participação no Governo Lula: avanços e inovações}

A participação popular se transformou na bandeira de muitos partidos e movimentos de esquerda, principalmente, durante a década de redemocratização nos anos 1980, sendo vista como uma ferramenta para superar as relações desiguais de poder e aprofundar a democracia (GOLDFRANK, 2015). Diversos princípios participativos como a adoção de mecanismos de democracia direta, de cotas parlamentares e partidárias, a instituição de conselhos cidadãos, orçamentos participativos, mecanismos de prestação de contas entre outras políticas vem sendo implementadas por distintos governos - locais, regionais e nacionais - e debatidas por estudiosos como processos de inovação democrática (SANTOS; AVRITZER, 2002; DAGNINO; OLVERA; PANFICHI, 2006).

O Brasil, neste sentido, se constituiu como uma referência para a participação. Sua estrutura participativa está vinculada ao movimento de descentralização de políticas públicas, ao processo de elaboração da Constituição de 1988 e às experiências das administrações petistas nas esferas municipais e estaduais (ROMÃO, 2015). Assim, quando Lula (PT) assumiu o poder em 2003, já contava com alguns recursos políticos favoráveis à implementação de políticas participativas. Veremos que em sua gestão, ainda que com alguns limites, novos mecanismos de participação foram criados e os mecanismos existentes foram ampliados, reformulados e utilizados com maior intensidade, comparado aos governos anteriores. A nosso ver, esta relação com a participação condiz com o projeto político do PT e da própria esquerda, de buscar a igualdade e equidade através da redução das desigualdades e da promoção de governos mais inclusivos. Para entender as inovações e avanços quanto à participação no governo Lula, esta seção está centrada em dois eixos analíticos: i) os mecanismos de participação e de inclusão criados pelo governo e; ii) as condições favoráveis à participação (Tabela 4). 
Tabela 4: Eixos Analíticos Participação

\begin{tabular}{|c|c|c|}
\hline Eixos analíticos & Variável & Indicadores \\
\hline \multirow{3}{*}{$\begin{array}{l}\text { Mecanismos de } \\
\text { Participação e } \\
\text { Inclusão }\end{array}$} & $\begin{array}{l}\text { Mecanismos de } \\
\text { Democracia direta }\end{array}$ & $\begin{array}{l}\text { Plebiscito, Referendos, Iniciativa Legislativa Popu- } \\
\text { lar, Veto popular. }\end{array}$ \\
\hline & $\begin{array}{l}\text { Instituições } \\
\text { Participativas }\end{array}$ & Conselhos, Conferências e Orçamento Participativo. \\
\hline & $\begin{array}{c}\text { Grau de } \\
\text { Representatividade }^{11}\end{array}$ & $\begin{array}{l}\text { Políticas de Inclusão (Cotas) e Representatividade de } \\
\text { mulheres, índios e negros na política. }\end{array}$ \\
\hline \multirow{5}{*}{$\begin{array}{l}\text { Condições } \\
\text { Favoráveis à } \\
\text { Participação }\end{array}$} & \multirow{3}{*}{ Educação } & Melhoria e acesso à Educação Básica. \\
\hline & & Taxa de alfabetização. \\
\hline & & Acesso à educação superior. \\
\hline & \multirow{2}{*}{ Desigualdade } & Índice de Gini. \\
\hline & & Índice de Pobreza e Indigência. \\
\hline
\end{tabular}

Fonte: Elaboração própria com base na literatura sobre participação.

O primeiro eixo "mecanismos de participação e inclusão" está relacionado com o pressuposto de que o aprofundamento da democracia liberal no sentido de sanar os déficits quanto à ausência de canais de participação e de representação perpassa pelo formato das instituições políticas e como os governos concebem tais questões.

O segundo eixo "condições favoráveis à participação" parte do pressuposto de que as condições de desigualdades levam a apatia política, obstruindo as oportunidades para a participação social. Logo, políticas de combate à pobreza e às desigualdades somadas às políticas de inclusão e de melhorias no acesso à educação são ensejos para a participação. As políticas participacionista, por sua vez, podem promover a participação e gerar recursos e capacidades para os indivíduos, possibilitando-os irromper contra as desigualdades sociais (VERBA, SCHOLOZMAN; BRADY, 2005).

Neste sentido, os dois eixos estão conectados, pois para se ter uma sociedade mais participativa é necessário a redução das desigualdades, "mas não podemos conseguir as mudanças da desigualdade social e na consciência [popular] sem um aumento antes da participação democrática" (MACPHERSON, 1978, p.103).

\footnotetext{
${ }_{11}$ A variável "grau de representatividade", embora importante no processo de ampliação da participação, não será abordada diretamente neste trabalho, devido ao foco do artigo e limite de espaço. 


\subsection{Mecanismos de participação e inclusão}

Neste eixo, buscamos avaliar nos dois mandatos de Lula: a) os mecanismos de democracia direta, tais como plebiscitos, referendos, iniciativa legislativa e veto popular e; b) as instituições participativas, demonstrando a criação, reformulação e/ou ampliação de instituições como conselhos, conferências e orçamentos participativos.

\section{a) Mecanismos de Democracia Direta}

Os mecanismos de democracia direta se referem às consultas e às iniciativas populares. A consulta popular, que pode ser obrigatória ou facultativa, ocorre quando uma proposta, seja de reforma constitucional, de aprovação de textos legais ou sobre assuntos políticos de grande importância, é submetida ao voto popular - tais como, referendos e plebiscitos. As iniciativas populares, por sua vez, constituem o direito do cidadão de propor projetos de leis e reformas legais ou constitucionais (totais ou parciais) ao poder legislativo (ZOVATTO, 2010). Tais mecanismos contribuem para a conformação da democracia participativa, pois capacitam os cidadãos a participar dos assuntos públicos e asseguram a influência direta dos cidadãos no processo decisório e no controle dos governantes tornando-os responsáveis por suas ações (MORLINO, 2010). A análise desses mecanismos perpassa necessariamente pela análise da Constituição de um país.

A Constituição brasileira é anterior ao governo Lula. Promulgada em 1988, ficou conhecida como a "Constituição Cidadã" (CARVALHO, 2014), pois levou em consideração diversas questões hasteadas pelos movimentos sociais, que foram transformadas em diretrizes de diversas políticas, especialmente as políticas sociais. Dentre os mecanismos de democracia direta, a Constituição prevê plebiscito, referendo e iniciativa popular (Artigos 14, 49 e 84), além da participação cidadã, por meio de organizações representativas, na formulação e no controle das políticas públicas em matéria de assistência, seguridade social, trabalho e saúde (Artigos 10, 194, 198 e 204) (BRASIL, 1988). Estes artigos demonstram a estratégia contida na Constituição de se criar um sistema descentralizado e participativo especialmente, a partir dos conselhos e conferências - que "está relacionado à questão da democratização e da publicização do Estado" (MORONI, 2009, p.113).

Desde 1988, a consulta popular foi utilizada apenas duas vezes: primeiro, em 1993 com a realização do plebiscito, já previsto na Constituição de 1988, sobre o regime (Monarquia ou República) e o sistema político (Presidencialismo ou Parlamentarismo $)^{12}$. Segundo, em 2005, no primeiro mandato de Lula, com a

$\overline{12}$ O povo optou pela República (com $86 \%$ dos votos) e pelo presidencialismo (com $55,4 \%$ dos votos). 
realização do referendo sobre a proibição do comércio de arma de fogo no país. A proposta de proibição foi rejeitada com $62 \%$ dos votos (LISSIDINI, 2011, p.53). Esse resultado "pode ter gerado um desestímulo ao uso do instrumento de democracia direta, uma vez que a bancada que o convocou foi derrotada" (IPEA, 2010, p.241). Em relação às iniciativas populares, apenas quatro projetos tornaramse leis no Brasil: a Lei 8.930 de 1994 que inclui o homicídio qualificado no rol de crimes hediondos; a Lei 9840 de 1999 de combate à compra de votos através da cassação do mandato do condenado e pagamento de multa; a Lei 11.124 de 2005 sobre o Fundo Nacional de Habitação de Interesse Social, garantindo a população de menor renda o acesso à habitação e; a Lei 135 de 2010 - a Lei da Ficha Limpa, que torna inelegíveis para cargos eletivos pessoas que tenham cometido algum crime de natureza eleitoral ou alguma outra infração relacionada ao seu mandato. Todas essas leis advêm de iniciativas populares, através de movimentos sociais e entidades que coletaram milhares de assinaturas para encaminharem junto aos projetos à Câmara Federal. Contudo, esses projetos precisaram ser subscritos por algum coautor institucional e, portanto, não foram registrados como projeto popular, diante de empecilhos institucionais, tais como exigências do Tribunal Superior Eleitoral para a verificação de milhões de assinaturas coletadas (IPEA, 2010).

Embora a Constituição de 1988 apresente limites, ela se constituiu em um legado positivo para o governo Lula no processo de implementação de políticas participativas. Veremos, que apesar da consulta popular ter sido pouco utilizada pelo governo, houve um significativo aproveitamento das instituições participativas previstas na Constituição.

\section{b) Instituições Participativas}

As instituições participativas correspondem aos espaços em que os setores populares podem expressar-se, instrumentalizar suas demandas e fiscalizar seus representantes e o processo decisório. Portanto, a criação, o fortalecimento e a regulamentação dessas instituições significam um processo imprescindível para o aprimoramento da democracia, na medida em que articulam grupos sociais que passam a agir como sujeitos políticos coletivos e tornam a representação pluralista.

No Brasil, diversas instituições participativas tiveram sua origem no processo constituinte e foram normatizadas nos anos 1990, tais como os conselhos de políticas públicas, os conselhos tutelares e outras instituições de participação em nível local (AVRITZER, 2009).

Com o governo Lula (2003-2010) houve uma ampliação dessas instituições participativas. O governo buscou aumentar a participação dos atores na sociedade, institucionalizando uma relação direta entre o executivo e a sociedade, através da criação da Secretaria Geral da Presidência, que desenvolveu "um trabalho de 
consulta e articulação prévia com entidades e movimentos sociais das regiões que o presidente [iria] visitar, procurando identificar as pautas de reivindicação, as necessidades e os focos de tensão" existentes ${ }^{13}$ (LAMBERTUCCI, 2009, p.73 e 81).

O governo Lula fortaleceu os Conselhos Nacionais já existentes (saúde, assistência social, criança e adolescente e meio ambiente) e suas prerrogativas no controle de fundos e recursos públicos ${ }^{14}$ (AVRITZER; SILVA, 2009, p.7-8), bem como, criou novos conselhos, realizou várias conferências em diversas áreas, formulando as prioridades dos diferentes ministérios e, criou mesas de negociação com diversos movimentos sociais, em especial com o Movimento Sindical e o MST.

Segundo Avritzer (2009, p.28), o país passou a ter mais de 10 mil conselhos e mais conselheiros do que vereadores. Tais conselhos consistem em "instituições híbridas nas quais têm participação atores do Executivo e atores da sociedade civil relacionados com a área temática na qual o conselho atua". Todos adotam a paridade como princípio (AVRITZER, 2009) e constituem espaços fundamentalmente político, institucionalizado, de caráter deliberativo e consultivo, com a finalidade de elaboração, deliberação e controle da execução de políticas públicas (MORONI, 2009).

Gráfico 1: Criação dos Conselhos e Comissões Nacionais - Brasil (1931-2010)

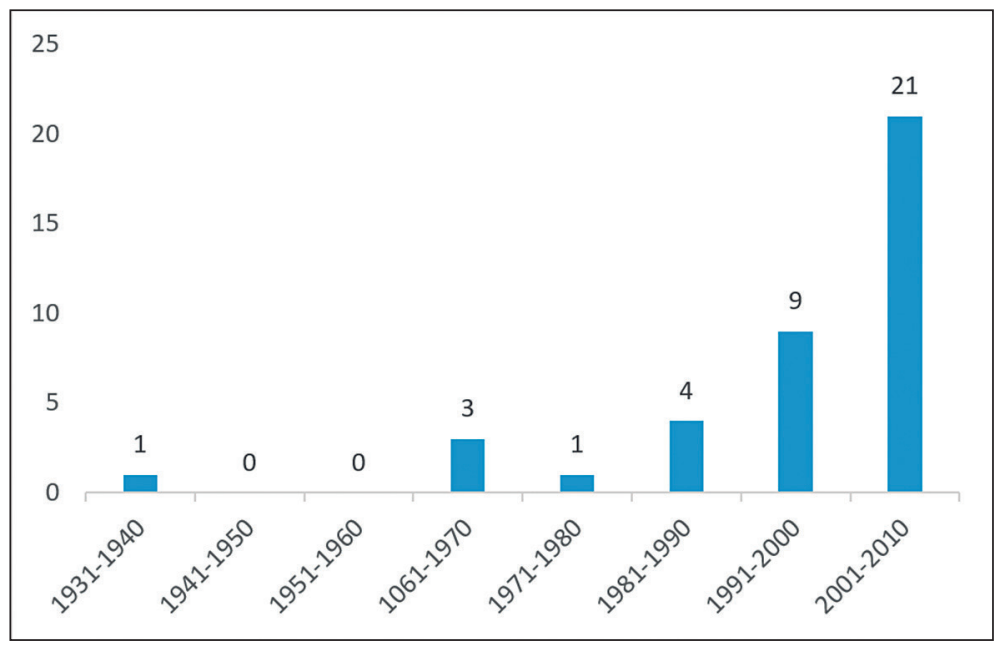

Fonte: Secretaria Geral da Presidência da República, 2013.

\footnotetext{
13 "Em dois anos e meio, mais de 1.500 encontros foram realizados [...] com representantes da sociedade civil [...]." (Discurso do Presidente Lula, no Foro Franco-Brasileiro da Sociedade Civil - Paris, França, 13/07/2005).

${ }^{14}$ Há Conselhos (nas áreas de saúde, assistência social, meio ambiente e educação) que são obrigatórios para que os municípios possam receber verbas públicas. Estes têm, entre suas atribuições, a função de fiscalizar a execução dos repasses de recursos (LAMBERTUCCI, 2009)
} 
Conforme informações do quadro 1, durante os dois mandatos de Lula, houve expansão dos conselhos nacionais. Muitos ministros passaram a frequentar as reuniões dos conselhos. No Conselho de Saúde, por exemplo, durante o governo Lula, 91\% das reuniões do conselho tiveram a presença do ministro, já no governo Fernando Henrique Cardoso (FHC) essa porcentagem foi de apenas 14\% (AVRITZER, 2009).

Quadro 1: Conselhos e Comissões Criadas Durante o Governo Lula (2003-2010)

\begin{tabular}{|c|c|}
\hline Ano & Conselhos ou Comissões Nacionais \\
\hline \multirow{7}{*}{2003} & Comissão Nacional para Erradicação do Trabalho Escravo (Conatrae) \\
\hline & Conselho Nacional de Economia Solidária (CNES) \\
\hline & Conselho de Desenvolvimento Econômico e Social (CDES) \\
\hline & Conselho Nacional de Recursos Hídricos (CNRH) \\
\hline & Conselho de Transparência Pública e Combate à Corrupção (CTPCC) \\
\hline & Conselho Nacional de Aquicultura e Pesca (Conape) \\
\hline & Conselho Nacional de Promoção da Igualdade Racial (CNPIR) \\
\hline \multirow{2}{*}{2005} & Conselho Nacional de Juventude (Conjuve) \\
\hline & Conselho Nacional de Política Cultural (CNPC) \\
\hline \multirow{4}{*}{2006} & Comissão Nacional de Política Indigenista (CNPI) \\
\hline & Conselho Nacional de Política Sobre Drogas (Conad) \\
\hline & $\begin{array}{l}\text { Comissão Nacional de Desenvolvimento Sustentável dos Povos e Comunidades } \\
\text { Tradicionais (CNPCT) }\end{array}$ \\
\hline & Conselho das Cidades (Concidades) \\
\hline 2007 & Conselho Nacional de Ciência e Tecnologia (CCT) \\
\hline \multirow{2}{*}{2008} & Conselho Curador Empresa Brasil de Comunicação \\
\hline & Conselho Nacional dos Direitos da Mulher (CNDM) \\
\hline \multirow{2}{*}{2010} & Conselho de Relações do Trabalho (CRT) \\
\hline & Conselho Nacional de Proteção e Defesa Civil (Condec) \\
\hline
\end{tabular}

Fonte: Secretaria Geral da Presidência da República, 2013.

Também, pode-se observar um aumento da participação nas Conferências Nacionais, que são "espaços institucionais de deliberação de diretrizes gerais de determinada política pública" (MORONI, 2009, p.115). Trata-se de uma estrutura piramidal de participação e representação, pois são realizadas em etapas - municipais e estaduais - com a função de coletar propostas e, também, eleger delegados que terão a missão de levar as propostas priorizadas pela plenária das conferências aos níveis mais elevados, até o nível nacional (ROMÃO, 2015). 
A quantidade de Conferências realizadas durante a gestão de Lula foi expressiva quando comparada com o governo de FHC que somadas em seus dois mandatos dá um total de 29. Só no primeiro mandato de Lula foram realizadas 36 Conferências Nacionais e 38 no seu segundo mandato (Tabela 5).

Tabela 5: Conferências Nacionais Realizadas entre 1995-2010 - Brasil

\begin{tabular}{|c|c|c|c|c|}
\hline Conferências & 1995-1998 & 1999-2002 & 2003-2006 & 2007-2010 \\
\hline $\begin{array}{l}\text { Conferência Brasileira de } \\
\text { Arranjos Produtivos Locais }\end{array}$ & & & 2 & 2 \\
\hline $\begin{array}{c}\text { Conferência das Comunidades } \\
\text { Brasileiras no Exterior }\end{array}$ & & & & 3 \\
\hline Conferência Nacional das Cidades & & & 2 & 2 \\
\hline $\begin{array}{c}\text { Conferência Nacional de } \\
\text { Aprendizagem Profissional }\end{array}$ & & & & 1 \\
\hline $\begin{array}{l}\text { Conferência Nacional de } \\
\text { Aquicultura e Pesca }\end{array}$ & & & 2 & 1 \\
\hline $\begin{array}{l}\text { Conferência Nacional de } \\
\text { Assistência Social }\end{array}$ & 2 & 1 & 2 & 2 \\
\hline $\begin{array}{l}\text { Conferência Nacional de Ciência, } \\
\text { Tecnologia e Inovação }\end{array}$ & & 1 & 1 & 1 \\
\hline $\begin{array}{l}\text { Conferência Nacional de Ciência, } \\
\text { Tecnologia e Inovação em Saúde }\end{array}$ & & & 1 & \\
\hline $\begin{array}{l}\text { Conferência Nacional } \\
\text { de Comunicação }\end{array}$ & & & & 1 \\
\hline Conferência Nacional de Cultura & & & 1 & 1 \\
\hline $\begin{array}{l}\text { Conferência Nacional de Defesa } \\
\text { Civil e Assistência Humanitária }\end{array}$ & & & & 1 \\
\hline $\begin{array}{c}\text { Conferência Nacional } \\
\text { de Desenvolvimento } \\
\text { Rural Sustentável }\end{array}$ & & & & 1 \\
\hline $\begin{array}{c}\text { Conferência Nacional de } \\
\text { Direitos Humanos }\end{array}$ & 3 & 4 & 3 & 1 \\
\hline $\begin{array}{l}\text { Conferência Nacional de } \\
\text { Economia Solidária }\end{array}$ & & & 1 & 1 \\
\hline Conferência Nacional de Educação & & & & 1 \\
\hline $\begin{array}{l}\text { Conferência Nacional } \\
\text { de Educação Básica }\end{array}$ & & & & 1 \\
\hline $\begin{array}{l}\text { Conferência Nacional de } \\
\text { Educação Escolar Indígena }\end{array}$ & & & & 1 \\
\hline
\end{tabular}




\begin{tabular}{|c|c|c|c|c|}
\hline Conferências & 1995-1998 & 1999-2002 & 2003-2006 & 2007-2010 \\
\hline $\begin{array}{c}\text { Conferência Nacional de Educação } \\
\text { Profissional Tecnológica }\end{array}$ & & & 1 & \\
\hline $\begin{array}{l}\text { Conferência Nacional de } \\
\text { Gays, Lésbicas, Bissexuais, } \\
\text { Travestis e Transexuais }\end{array}$ & & & & 1 \\
\hline $\begin{array}{l}\text { Conferência Nacional de Gestão do } \\
\text { Trabalho e da Educação na Saúde }\end{array}$ & & & 1 & \\
\hline Conferência Nacional de Juventude & & & & 1 \\
\hline $\begin{array}{l}\text { Conferência Nacional de } \\
\text { Medicamentos e Assistência } \\
\text { Farmacêutica }\end{array}$ & & & 1 & \\
\hline $\begin{array}{l}\text { Conferência Nacional de Políticas } \\
\text { de Promoção da Igualdade Racial }\end{array}$ & & & 1 & 1 \\
\hline $\begin{array}{l}\text { Conferência Nacional de } \\
\text { Políticas para as Mulheres }\end{array}$ & & & 1 & 1 \\
\hline $\begin{array}{c}\text { Conferência Nacional de } \\
\text { Recursos Humanos da } \\
\text { Administração Pública Federal }\end{array}$ & & & & 1 \\
\hline Conferência Nacional de Saúde & 1 & 1 & 1 & 1 \\
\hline $\begin{array}{c}\text { Conferência Nacional } \\
\text { de Saúde Ambiental }\end{array}$ & & & & 1 \\
\hline $\begin{array}{c}\text { Conferência Nacional } \\
\text { de Saúde Bucal }\end{array}$ & & & 1 & \\
\hline $\begin{array}{l}\text { Conferência Nacional de } \\
\text { Saúde do Trabalhador }\end{array}$ & & & 1 & \\
\hline $\begin{array}{l}\text { Conferência Nacional } \\
\text { de Saúde Indígena }\end{array}$ & & 1 & 1 & \\
\hline $\begin{array}{c}\text { Conferência Nacional } \\
\text { de Saúde Mental }\end{array}$ & & 1 & & 1 \\
\hline $\begin{array}{c}\text { Conferência Nacional de } \\
\text { Segurança Alimentar e Nutricional }\end{array}$ & & & 1 & 1 \\
\hline $\begin{array}{c}\text { Conferência Nacional de } \\
\text { Segurança Pública }\end{array}$ & & & & 1 \\
\hline Conferência Nacional do Esporte & & & 2 & 1 \\
\hline $\begin{array}{c}\text { Conferência Nacional } \\
\text { do Meio Ambiente }\end{array}$ & & & 2 & 1 \\
\hline $\begin{array}{c}\text { Conferência Nacional dos Direitos } \\
\text { da Criança e do Adolescente }\end{array}$ & 2 & 2 & 2 & 2 \\
\hline $\begin{array}{l}\text { Conferência Nacional dos Direitos } \\
\text { da Pessoa com Deficiência }\end{array}$ & & & 1 & 1 \\
\hline
\end{tabular}




\begin{tabular}{c|c|c|c|c}
\hline Conferências & $\mathbf{1 9 9 5 - 1 9 9 8}$ & $\mathbf{1 9 9 9 - 2 0 0 2}$ & $\mathbf{2 0 0 3 - 2 0 0 6}$ & $\mathbf{2 0 0 7 - 2 0 1 0}$ \\
\hline $\begin{array}{c}\text { Conferência Nacional dos } \\
\text { Direitos da Pessoa Idosa }\end{array}$ & & & 1 & 1 \\
\hline $\begin{array}{c}\text { Conferência Nacional } \\
\text { dos Povos Indígenas }\end{array}$ & & 1 & 1 \\
\hline $\begin{array}{c}\text { Conferência Nacional Infanto- } \\
\text { Juvenil pelo Meio Ambiente }\end{array}$ & & & 2 & 1 \\
\hline
\end{tabular}

Fonte: Secretaria Geral da República (2014). Disponível em: http://www.secretariageral.gov.br/ participacao-social/conferencias/conferencias-nacionais-tabela-2014/view.

As 74 Conferências realizadas durante os dois mandatos de Lula contaram com a participação de mais de 5 milhões de brasileiros. Estas foram relevantes, pois além de criar uma agenda da sociedade civil em áreas importantes, as resoluções aprovadas tornaram-se diretrizes para o estabelecimento de políticas públicas (AVRITZER, 2015; LAMBERTUCCI, 2009). O I e o II Plano Nacional de Políticas para as Mulheres, por exemplo, publicados respectivamente em 2004 e 2008, foram elaborados a partir das diretrizes provindas das Conferências Nacionais. Segundo Pogrebinschi e Samuels (2014), quase metade das políticas públicas legisladas ou decretadas sobre o tema das mulheres é consistente com as propostas advindas das Conferências, incluindo a lei Maria da Penha ${ }^{15}$ (Lei $\left.n^{\circ} 11.340 / 2006\right)$, sancionada pelo então presidente Lula e, que constitui em um importante instrumento em defesa das mulheres vítimas de violência. Contudo, vale ressaltar que as pressões de bancadas conservadoras no Congresso barraram várias recomendações das Conferências, como as que tratavam do direito reprodutivo da mulher.

Ainda foram criadas mesas de diálogo com objetivo de prevenir ou solucionar conflitos. Nestes espaços, várias propostas foram formuladas, de modo consensual, contemplando as demandas sociais e respeitando os limites legais e orçamentários. Um exemplo, foram as políticas de salário-mínimo e de agricultura familiar (LAMBERTUCCI, 2009). Houve também, a participação da sociedade no processo de construção do Plano Plurianual (PPA) 2004-2007. Em 2007, o executivo publicou um decreto, instituindo, no âmbito do Ministério do Planejamento, Orçamento e Gestão, um Grupo de Trabalho, com a objetivo de "elaborar propostas de participação social no acompanhamento da elaboração e execução do Plano Plurianual, da Lei de Diretrizes Orçamentárias e da Lei Orçamentária Anual” (MORONI, 2009, p.131).

O Orçamento Participativo (OP), iniciado a partir de 1990 com as experiências das administrações petista em Porto Alegre, Belo Horizonte, São Paulo e Recife, constitui um dos casos exitosos por apresentar um desenho participativo de baixo

\footnotetext{
${ }^{15}$ Esse nome se refere ao caso $n^{\circ} 12.051 / O E A$ de Maria da Penha Maia Fernandes, vítima de violência doméstica durante 23 anos de casamento (OEA, 2001).
} 
para cima, sendo fortemente democratizante, embora, o mais vulnerável à vontade política (AVRITZER, 2015). Das 53 experiências de OPs que havia em 1997, $62 \%$ estavam concentradas nas cidades governadas pelo PT e $72 \%$ delas estavam concentradas no campo da esquerda (PSB, PDT e PCdoB). Entre 2000 e 2004, o número de experiências de OP saltou para 170, das quais $47 \%$ estavam concentradas no PT e 57\% no campo da esquerda (AVRITZER, 2009, p.39). Com o sucesso dos OPs, outros partidos como o PMDB e o PSDB também passaram a adotá-los nas suas administrações. Todavia, o governo Lula não conseguiu estender estas experiências do âmbito municipal e regional para o âmbito nacional. Havia uma dificuldade em se criar uma nova "arquitetura da participação", pois como aponta Pedro Pontual em entrevista a Lavalle e Szwako (2014, p.96), "no governo Lula, continuavam convivendo conflituosamente o agronegócio e a agricultura familiar", só para citar uma das correlações de forças presente no processo de formulação de políticas públicas.

No final do segundo mandato de Lula surgiu o debate sobre a institucionalização das políticas de participação social e a criação do Sistema Nacional de Participação Social, porém, o projeto não foi encaminhado ao Congresso. Nas palavras de Pontual: "Tinha-se uma avaliação de que ele dificilmente seria aprovado no último ano de governo com toda a disputa eleitoral. Isso fez refluir um pouco a discussão interna sobre o sistema de participação" (LAVALLE; SZWAKO, 2014, p.96).

Como vimos, no que se refere às instituições participativas, é inegável o fortalecimento destas e a ampliação dos espaços para o debate das políticas públicas, ainda que a proposta de institucionalização e integração dessas políticas participativas tenham ficado para o governo de Dilma Rousseff $(\mathrm{PT})^{16}$.

\section{Condições Favoráveis à Participação}

Como apontamos, as condições de desigualdades limitam a participação cidadã, o que por sua vez, gera desigualdade de representação. Portanto, como afirma Macpherson (1978), se faz necessário promover mudanças que estimulem a participação e ao mesmo tempo que reduzam as desigualdades, possibilitando a concretização dos direitos iguais de todo homem e de toda mulher ao autodesenvolvimento e ao emprego de suas capacidades. Autores como Amartya Sen (2010) e Guillermo O’Donnell (2011) também compartilham dessa perspectiva. Na análise de Sen (2010, p. 191), por exemplo, "a criação de oportunidades sociais contribui para a expansão das capacidades humanas e da qualidade de vida”. Para O’Donnell (2011,

\footnotetext{
${ }^{16}$ Em 2014, a ex-presidente Dilma Rousseff instituiu, por meio do Decreto n8.243/2014, a Política Nacional de Participação Social (PNPS) e o Sistema Nacional de Participação Nacional (SNPS). Porém, a Câmara aprovou um projeto (PDC-1491/14) que cancela o decreto do governo. (SIQUEIRA, 2014).
} 
p.212), a democracia pressupõe os cidadãos como sujeitos políticos, portadores de capacidades decisórias, mas a agência ou o exercício da cidadania presume algumas liberdades básicas e direitos civis. Para tanto, é necessário a "provisão social de um mínimo de liberdades, direitos e capacidades que permitam exercer essa agência ou, pelo menos, não sofrer privações que a impeçam seriamente". Nesta mesma linha, Verba (2001, p.10) argumenta que "ter o direito legal de votar, falar ou participar de uma campanha política ou de uma organização precisa ser complementada pela capacidade de fazê-lo". O autor demonstra que o engajamento cívico, em suas diversas modalidades, é mais comum entre os indivíduos que ocupam posições centrais na estrutura social. Arretche (2015) também mostra a estreita relação entre escolaridade e participação política. Neste sentido, renda, educação e escolaridade tem se convertido em importantes determinantes para a participação cidadã (Ribeiro, 2013).

Portanto, neste eixo, buscamos analisar o quanto o governo Lula conseguiu criar condições favoráveis à participação através de políticas de melhorias no acesso à educação e de combate às desigualdades e à pobreza. Dentre as políticas sociais implementadas durante a gestão de Lula (2003-2010), estão o lançamento do Programa Fome Zero e a criação, através da Medida Provisória 132, do Programa Bolsa Família, ambos de 2003. Em 2004, o governo criou o Ministério do Desenvolvimento Social e Combate à Fome (MDS), que possibilitava, segundo Frei Betto (2007, p.423) "a integração maior de todas as políticas sociais, menos atomizadas", levando "ao aperfeiçoamento do controle social e uma presença maior do Estado, transformando em políticas públicas a assistência social e o combate à fome". Ademais, como apontamos, o governo criou a política de valorização do salário-mínimo, que permitiu incrementar a capacidade de compra de milhões de brasileiros em $45 \%$ já no primeiro mandato de Lula (NATANSON, 2009) e fez com que 29 milhões de pessoas ingressassem nas fileiras da chamada nova classe média (Classe C) entre 2003 e 2009 (NERI, 2010).

O programa Fome Zero tinha como intuito articular transferência de renda (Bolsa Família), políticas estruturais (como a Reforma Agrária e o fortalecimento da agricultura familiar) e ações educativas. Os programas deveriam ser fiscalizados pelos Comitês Gestores, que no início do programa já estavam presentes em mais de 2 mil municípios. No entanto, havia divergências entre o Ministro Patrus Ananias do MDS, que priorizava a parceria com prefeitos e governos estaduais, e o coordenador do Programa Fome Zero - Frei Betto, que defendia os Comitês Gestores na função de implementar e fiscalizar as ações do programa, sem excluir os entes federativos. Nessa correlação de forças, "De gestores do Fome Zero, os comitês - ou o que [sobrou] deles - passaram [...] a meros colaboradores da União e das prefeituras" (BETTO, 2007, p.427). O fato é que estas divergências demonstravam as pressões daqueles que defendiam apenas políticas compensatórias e os que queriam políticas que promovessem mudanças estruturais com a participação da sociedade. Ao longo 
do governo, o Fome Zero foi perdendo espaço, como pode ser observado no Decreto 5.209 de 2004 que regulamentou o Bolsa Família e não faz menção alguma ao Fome Zero e aos Comitês Gestores (BETTO, 2007).

O Bolsa Família consiste em um programa de transferência de renda condicionada $^{17}$, que integrou os programas do governo anterior como o Bolsa Escola, o Cartão Alimentação e o auxílio gás, porém, atendendo um maior número de famílias. Em 2003, 3,6 milhões de famílias eram atendidas pelo Bolsa Família, em 2006 já eram 11 milhões de famílias beneficiadas (MADRID, 2007-2008). Este programa foi considerado uma experiência excepcional e pioneira na redução da pobreza (BRASIL 247, 2013). Como demonstra o Gráfico 2, quando Lula assumiu o poder (2003), 14\% da população estava abaixo da linha da pobreza, em 2011 esse número caiu para $6,1 \%$. Neste mesmo período, a pobreza reduziu de $38,7 \%$ para $20,9 \%$.

Gráfico 2: População em Situação de Pobreza e Indigência* no Brasil

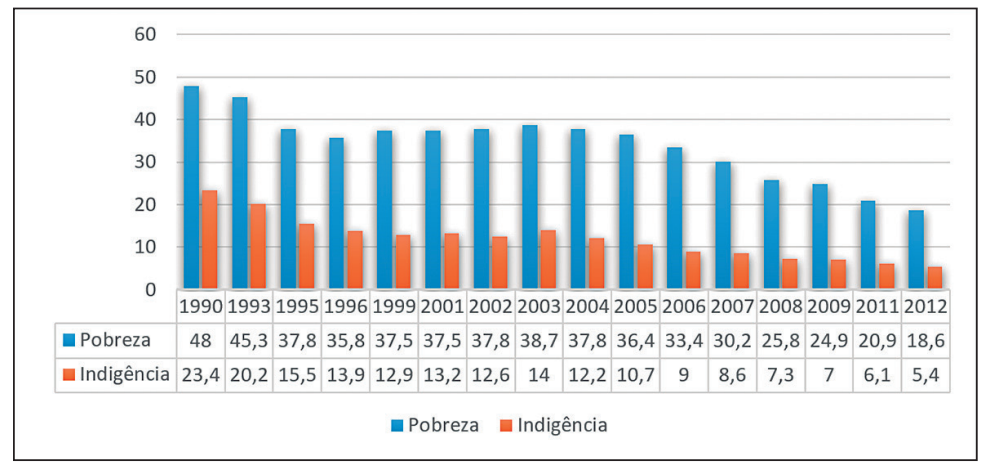

Fonte: Comisión Económica para América Latina y el Caribe (CEPAL)

Em relação às políticas para reduzir o índice de analfabetismo no Brasil, o governo Lula criou o Programa Brasil Alfabetizado, realizado pelo Ministério da Educação (MEC) desde 2003, o qual dá apoio técnico e financeiro na implementação das ações do programa, dando prioridade aos munícipios com alto índice de analfabetismo. Outros avanços, foram a instituição, pelo Decreto ${ }^{\circ} 4.834$ de 2003, da Comissão Nacional de Alfabetização e Educação de Jovens e Adultos (CNAEJA), de caráter consultivo, que assegura a participação da sociedade no Programa, e a criação, em 2004, da Secretaria de Educação Continuada, Alfabetização e Diversidade (Secad $)^{18}$ no MEC. A taxa de analfabetismo caiu de 11,6\% em 2003 para

\footnotetext{
${ }_{17}$ As famílias beneficiárias devem manter em dia o programa de vacinas infantis e cuidados da mulher gestante; assegurar a frequência dos filhos à escola; e, enviar os analfabetos à alfabetização.

18 Desde 2011, passou a ser Secretaria de Educação Continuada, Alfabetização e Diversidade e Inclusão (Secadi).
} 
8,6\% em 2011 (Gráfico 3). No entanto, ainda uma taxa alta comparada à barreira dos $3 \%$ estabelecidos pela Unesco para declarar o país "livre do analfabetismo".

Gráfico 3: Taxa de Analfabetismo por Grupo de

Idade (15 anos ou mais de idade) - Brasil

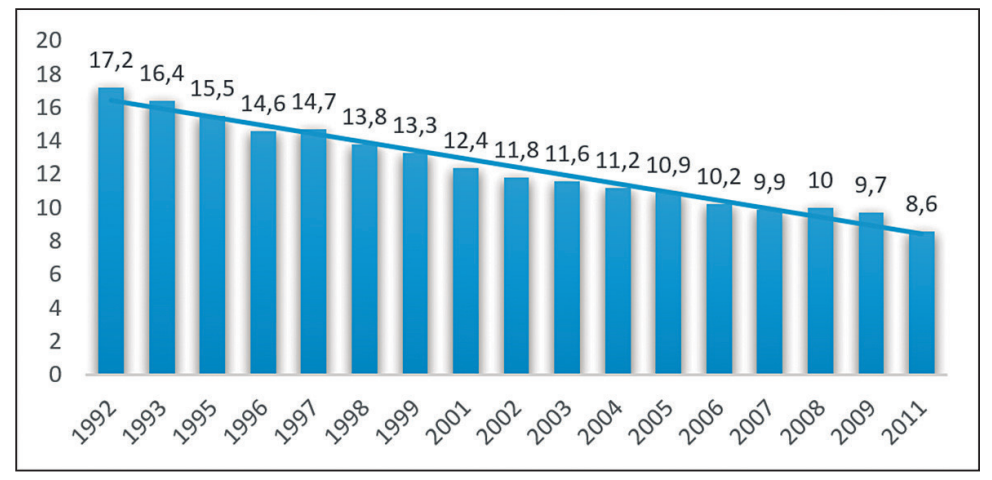

Fonte: IBGE, Pesquisa Nacional por Amostra de Domicílios (1992-2011).

Entre os anos de 2003 e 2011 houve um aumento de 2,2\% de crianças matriculadas no ensino fundamental e de $9,1 \%$ de jovens matriculados no ensino médio (Gráfico 4).

Gráfico 4: Porcentagem de Crianças (6 a 14 anos) e Jovens (15 a 17 anos) Matriculados no Ensino Fundamental e Médio - Brasil

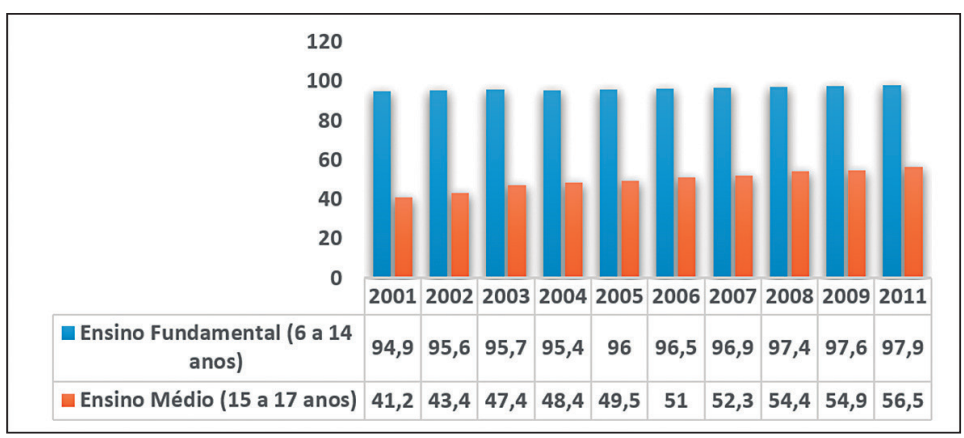

Fonte: Observatório do Plano Nacional de Educação (PNE)

Ao mesmo tempo também houve a expansão do ensino universitário com o Programa Universidade para Todos (Prouni), introduzido em 2005. Em 2000 estavam matriculados na graduação 2,7 milhões de pessoas, $67 \%$ destes em universidades 
particulares. Em 2011, esse número subiu para 6,7 milhões, respondendo às universidades particulares por 74\%. (CARVALHO, 2014).

Gráfico 5: Total de Alunos Matriculados na Educação Superior - Brasil

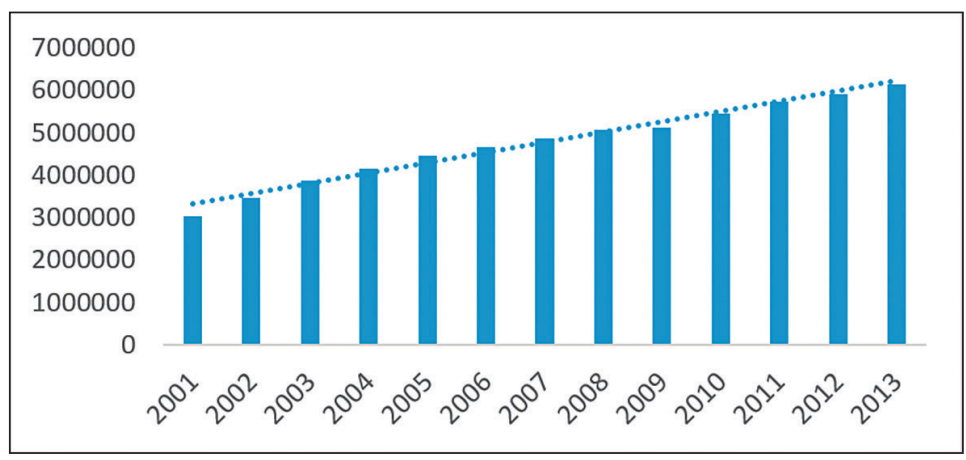

Fonte: Observatório do Plano Nacional de Educação (PNE)

Tais políticas refletiram no aumento significativo da escolaridade entre os $25 \%$ mais pobres entre 2001 e 2014 (Gráfico 6). Neste mesmo período, a escolaridade média da população negra entre 18 e 29 anos também aumentou expressivamente de 6,6 para 9,5 (anos de estudos).

Gráfico 6: Escolaridade Média da População de 18 a 29 anos $25 \%$ Mais Pobres (em anos de estudo) - Brasil

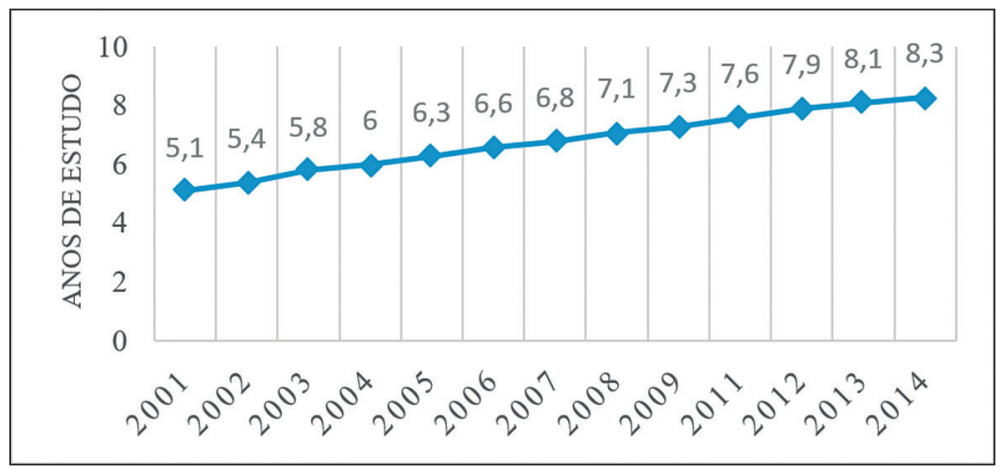

Fonte: Observatório do Plano Nacional de Educação (PNE)

A Lei Ordinária 10.558/2002 - conhecida como a Lei de $\operatorname{cotas}^{19}$ - que criou o Programa Diversidade na Universidade, visando o acesso ao ensino superior de

\footnotetext{
${ }_{19}$ Em 2012, no governo de Dilma Rousseff (PT) foi sancionada a Lei de Cotas $n^{\circ}$ 12.711/2012 que garante a reserva de $50 \%$ das matrículas nas Universidades e Institutos Federais a alunos oriundos
} 
grupos socialmente desfavorecidos, em especial os afrodescendentes e indígenas, foi uma importante contribuição do governo petista e que favorece o acesso destes grupos à postos nunca antes ocupados por eles.

Segundo Carvalho (2014, p.242), o aumento do poder de compra, devido a política salarial junto com a expansão de vagas no ensino superior, produziu uma nova geração de filhos da classe $\mathrm{C}$ com diploma universitário, que em geral, "são mais informados e mais críticos em relação a práticas governamentais". Para o autor, o "crescimento dessa nova camada social tem levado, ainda, a maior grau de exigência em relação a serviços públicos, como saúde, educação, segurança".

A atenção dada pelo governo aos setores mais pobres e excluídos refletiu na redução da desigualdade no país. O índice de Gini no Brasil reduziu de 0,621, em 2003, para 0,559 em 2011 (Gráfico 7).

Gráfico 7: Índice de Concentração de Gini no Brasil* (Valores entre 0 e 1)

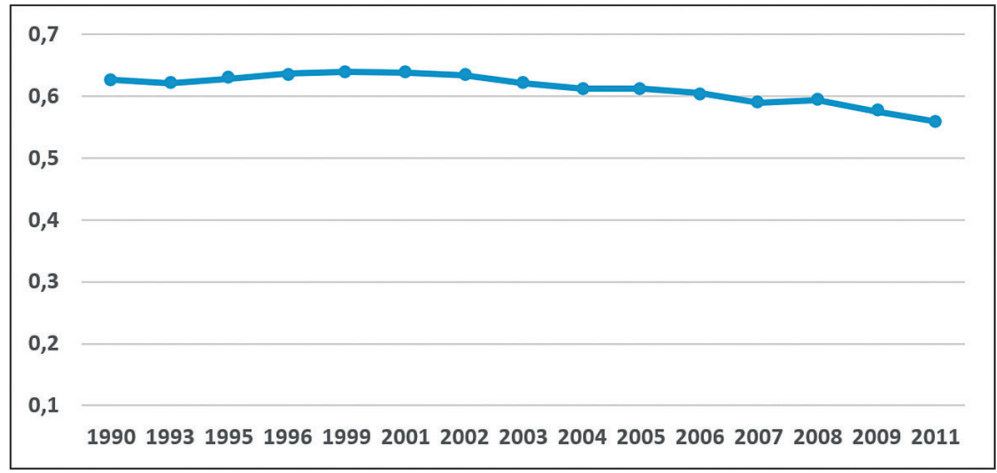

* O índice de Gini vai de 0 a 1, em que 1 representa a máxima desigualdade e 0 a perfeita igualdade.

Fonte: Comisión Económica para América Latina y el Caribe (CEPAL)

$\mathrm{O}$ número de decretos presidenciais destinados às minorias foi proeminente (PROGREBINSCHI; SAMUELS, 2014). Foram implementadas políticas de inclusão dos grupos minoritários e de combate à discriminação: como a criação, em 2006, da Comissão Nacional de Política Indigenista (CNPI) e a instituição de um fórum de discussão com a população indígena, a respeito da elaboração de políticas públicas federais, bem como, da atualização do Estatuto do Índio ${ }^{20}$ (BANIWA, 2011); a instituição do Estatuto da Igualdade Racial (Lei 12.288 de 20 de julho de 2010) e das leis federais $n^{\circ} 10.639$ de 2003 e $\mathrm{n}^{\circ} 11.645$ de 2008, que determinam a inclusão

integralmente do ensino médio público. (BRASIL, 2012).

${ }_{20}$ A proposta do Estatuto foi apresentada ao Congresso Nacional em 2009 e aprovada pelo decreto 7.778 de julho de 2012. 
de conteúdos relacionados à História e Cultura Afro-brasileiras e Indígenas nos currículos escolares, representando um importante passo para diminuir os efeitos do racismo na escola. Ademais, uma das medidas que marcou a pauta progressista do governo nesta questão foi a demarcação de uma das maiores reservas indígenas do país - reserva Raposa Serra do Sol. "No entanto, quando setores agrários passam a fazer parte da base do governo, ocorre a cisão em relação à política indígena" (AVRITZER, 2016, p.61).

A conciliação de interesses tão diversos, limitaram diversas políticas e a agenda participativa do governo. Os ruralistas, por exemplo, barraram parte do texto do Estatuto da Igualdade Racial que tratava da regularização de terras quilombolas, bem como, a decisão do governo Lula de mudar o índice de produtividade rural, critério utilizado para a distribuição de terras na reforma agrária (GONÇALVES, 2009).

Como podemos perceber, o governo logrou criar condições favoráveis à participação a medida em que houve uma redução da pobreza e da indigência e melhoria na educação através de políticas sociais destinadas, especialmente, aos setores marginalizados. Estas condições somadas à ampliação dos mecanismos de participação, por parte do governo, contribuem de maneira significativa para uma democracia mais participativa, criando oportunidades de maior participação popular no processo decisório e na fiscalização das políticas públicas. Todavia, também é possível perceber os limites impostos à agenda participacionista do governo. As pressões das bancadas dos ruralistas, de setores conservadores, de empresários ou dos governos estaduais e municipais demonstraram os impasses gerados às políticas estruturais que poderiam estabelecer de fato uma democracia mais participativa.

\section{Considerações Finais}

O objetivo deste artigo foi verificar como a correlação de forças políticas e a assimetria de recursos políticos impactaram no processo de implementação de mecanismos de participação nos governos Lula (2003-2010). Verificamos que os oito anos do governo passou por importantes impasses resultantes da configuração de forças políticas em sua coalizão governamental. Todavia, a boa interação com os movimentos sociais, a alta popularidade e legitimidade do presidente Lula e seu poder de negociação diante de diversos interesses sociais e econômicos garantiram governabilidade suficiente para o governo petista conseguir avanços na área de participação, com destaque ao incentivo, criação e reformulação das instituições participativas, como os Conselhos e Conferências Nacionais. Ademais, as políticas como o bolsa família, o aumento sucessivo do salário-mínimo e as políticas de acesso à educação para grupos marginalizados contribuíram para reduzir a pobreza, 
o analfabetismo e, de forma menos expressiva, a desigualdade social, gerando, assim, condições favoráveis à participação.

Foi importante para esses resultados, a Constituição de 1988 por já conter mecanismos de democracia direta e de participação, o que favoreceu a implementação dessas políticas participativas. Contudo, é possível perceber limites nesse processo impostos pela correlação de forças que o governo enfrentou. Dentre os limites, podemos citar o nosso presidencialismo de coalizão e a baixa representatividade do partido do presidente, impondo para a governabilidade a necessidade de construção de uma coalizão ampla e heterogênea ideologicamente, o que fez com que o governo tivesse que negociar cada tema da agenda com interesses distintos e contraditórios. A busca por conciliar esses interesses limitou o governo na adoção de políticas estruturais tão necessárias para o real fortalecimento da democracia. Três exemplos que demonstraram o impacto da correlação de forças no processo de implementação de políticas que favoreceriam a participação são: o fracasso do programa Fome Zero que esbarrou nos interesses dos prefeitos e dos governos estaduais, o teor que ganhou as políticas ambientalistas e indígenas que diante da bancada ruralista, a participação popular foi deixada de lado e, a pressão de setores conservadores - como a bancada dos evangélicos - contra diversas recomendações advindas das Conferências Nacionais das Mulheres.

Neste sentido, o governo Lula se caracterizou pela conciliação de diversos interesses, atendendo uns e apaziguando outros como forma de manter a governabilidade. O resultado foi um governo que buscou fortalecer a democracia, porém sem romper com a ordem institucional, articulando estratégias que priorizaram em certa medida o papel do Estado na condução de políticas econômicas e priorizando políticas de inclusão e de participação, mas sem promover mudanças estruturais que pudessem tornar a democracia brasileira de fato participativa.

\section{The governorships of LULA Da Silva aNd DEADLOCKS TO PARTICIPATION IN BRAZIL}

ABSTRACT: The purpose of this article is to verify how the correlation of forces and the asymmetry of political resources impacted the process of implementing mechanisms for participation in Lula da Silva's governorships (2003-2010). In order to do so, we carried out a case study focusing on two dimensions: a) correlation of political and economic forces - with the party opposition and business sectors and b) political resources - from institutional legacies, the political system, the agreements and the social support base. We concluded that despite the institutional deadlocks and the ideologically heterogeneous correlation of political forces, there 
have been advances in relation to political participation and access to social goods from sectors which were previously marginalized.

KEYWORD: Participation. Lula da Silva Government. Liberal Democracy. Conciliation between classes.

\section{LOS gobIernos de LULA DA Silva y LOS IMPASES A LA PARTICIPACIÓN EN BRASIL}

RESUMEN: El objetivo de este artículo es verificar cómo la correlación de fuerzas y la asimetría de recursos políticos impactaron en el proceso de implementación de los mecanismos de participación en los gobiernos de Lula da Silva (20032010). Para ello, realizamos un estudio de caso centrado en dos dimensiones: a) la correlación de fuerzas políticas y económicas -con la oposición partidista y los sectores empresariales- y b) los recursos politicos -derivados de los legados institucionales, el sistema político, los pactos y la base de apoyo social-. Concluimos que, a pesar de los impases institucionales y de la correlación de fuerzas políticas ideológicamente heterogénea, hubo avances en relación con la participación politica y el acceso a los bienes sociales por parte de sectores hasta entonces marginados.

PALABRAS CLAVE: Participación. Gobierno de Lula da Silva. Democracia liberal. Conciliación entre clases.

\section{REFERÊNCIAS}

ABRANCHES, Sérgio. Presidencialismo de coalizão: raízes e evolução do modelo político brasileiro. São Paulo: Companhia das Letras, 2018.

AMORIM NETO, Octavio. O Poder Executivo, centro de gravidade do sistema político brasileiro. In: AVELAR, Lúcia; CINTRA, Antônio Octávio (Org.). Sistema político brasileiro: uma introdução. 2 ed. Rio de Janeiro: Konrad-Adenauer-Stiftung; São Paulo: UNESP, 2007.

ARRETCHE, Marta (Org.). Trajetórias das desigualdades: como o Brasil mudou nos últimos cinquenta anos. São Paulo: Editora Unesp; CEM, 2015.

AVRITZER, Leonardo. Impasses da democracia no Brasil. Rio de Janeiro: Civilização Brasileira, 2016. 
AVRITZER, Leonardo. A participação no Brasil democrático e seu desenho institucional. In: AVELAR, Lúcia; CINTRA, Antônio Octávio (Org.). Sistema político brasileiro: uma introdução. 3 ed. Rio de Janeiro: Konrad-Adenauer-Stiftung; São Paulo: UNESP, 2015.

AVRITZER, Leonardo. Sociedade civil e participação no Brasil democrático. In: AVRITZER, Leonardo (org.). Experiências nacionais de participação social. São Paulo: Cortez, 2009. p. 27-54.

AVRITZER, Leonardo; SILVA, Eduardo Moreira da. Introdução. In: AVRITZER, Leonardo (org.). Experiências nacionais de participação social. São Paulo: Cortez, 2009. p.7-12.

BANIWA, André Fernando. Participação Política e Políticas Públicas para os Povos Indígenas no Brasil. In: CÁRDENAS, Víctor Hugo et al. Participación Política Indígena y Políticas Públicas para Pueblos Indígenas en América Latina. Bolívia: Fundación Konrad Adenauer, 2011.

BARBOSA, Nelson. Dez anos de política econômica. In: SADER, Emir (Org.) 10 anos de governos pós-neoliberais no Brasil: Lula e Dilma. São Paulo, SP: Boitempo: Rio de Janeiro: FLACSO Brasil, 2013.

BETTO, Frei. Calendário do poder. Rio de Janeiro: Rocco, 2007.

BRASIL. Presidência da República Casa Civil. Subchefia para Assuntos Jurídicos. LEI $\mathrm{N}^{\circ}$ 12.711, DE 29 DE AGOSTO DE 2012. Disponível em: http://www.planalto.gov.br/ ccivil_03/_ato2011-2014/2012/lei/112711.htm. Acesso em: 07 mar. 2021.

BRASIL. Tribunal Superior Eleitoral. Relatório das eleições 2002. Brasília: TSE, 2003. Disponível em: https://www.justicaeleitoral.jus.br/arquivos/tse-relarorio-resultadoeleicoes-2002. Acesso em: 07 mar. 2021.

BRASIL. Constituição da República Federativa do Brasil. Brasília, DF, Senado, 1988.

BRASIL 247. Bolsa Família vence prêmio ISSA, o Nobel social. Publicado em 15 de outubro de 2013. Disponível em: http://www.brasil247.com/pt/247/brasil/117868/BolsaFam\%C3\%ADlia-vence-pr\%C3\%AAmio-ISSA-o-Nobel-social.htm. Acesso em: 07 mar. 2021.

CARVALHO, José Murilo de. Cidadania no Brasil: o longo caminho. 18 ed. Rio de Janeiro: Civilização Brasileira, 2014.

CLEARY, Matthew R. A. "Left Turn" in Latin America? Explaining the left's resurgence. Journal of Democracy, volume 12, n 4, out. 2006.

COLIGAÇÃo lula PRESIDENTE. Programa de Governo 2002. Resoluções de Encontros e Congressos \& Programas de Governo, Partido dos Trabalhadores. Fundação Perseu Abramo, 2002. 
DAGNINO, Evelina; OLVERA, Alberto J.; PANFICHI, Aldo. A disputa pela construção democrática na América Latina. São Paulo: Paz e Terra; São Paulo: UNICAMP, 2006.

EASTON, David. Política Moderna. México: Editorial Letras, S. A., 1968.

FREITAS, Andréa. O presidencialismo da coalizão. Rio de Janeiro: Fundação Konrad Adenauer, 2016.

GONÇALVES, André. Bancadas que mandam no Congresso. Gazeta do Povo. Publicado em 19 de setembro de 2009. Disponível em: https://www.gazetadopovo.com.br/vida-publica/ bancadas-que-mandam-no-congresso-bwl1 fdtji2m20dulrgze36w5q/. Acesso em: 07 mar. 2021.

GOLDFRANK, Benjamin. Democracia participativa e izquierdas: logros, contradicciones y desafios. In: MINNAERT, Anja; ENDARA, Gustavo. Democracia Participativa e Izquierdas: logros, contradicciones y desafíos. Ecuador: FES-ILDIS, 2015.

IPEA. Estado, instituições e democracia: democracia. Série Eixos Estratégicos do Desenvolvimento Brasileiro; Fortalecimento do Estado, das Instituições e da Democracia; Livro 9. Brasília: Ipea, 2010.

LAMBERTUCCI, Antônio Roberto. A participação Social no Governo Lula. In: AVRITZER, Leonardo (org.). 2009. Experiências nacionais de participação social. São Paulo: Cortez, 2009. p. 70-89.

LAVALLE, Adrian G.; SZWAKO, José. Origens da política nacional de participação social. Entrevista com Pedro Pontual. Novos Estudos-Cebrap, n. 99, p. 91-104, julho, 2014.

LINZ, Juan. La Quiebra de las Democracias. Madrid: Alianza Editorial, 1991.

LISSIDINI, Alicia. Democracia directa en Latinoamérica: Entre la delegación y la participación. 1 ed. Buenos Aires: CLACSO, 2011.

MACPHERSON, Crawford B. A democracia Liberal: Origens e evolução. Rio de Janeiro: Zahar Editores [1977], 1978.

MADRID, Raúl. Leftist Government in Lati n America: A Comparison of Bolivia, Brazil, Chile, and Venezuela. Llilas Portal, $n^{\circ}$ 3, 2007-2008. Disponível em: http://lanic.utexas. edu/project/etext/liilas/portal/portal089/. Acesso em: 18 jun. 2015.

MORLINO, Leonardo. Teoria da democratização, qualidade da democracia e pesquisa de opinião: ainda em “mesas separadas"? In: MOISÉS, José Álvaro (Org). Democracia e Confiança: Por que os cidadãos desconfiam das instituições públicas? São Paulo: Edusp, 2010.

MORONI, José Antônio. O direito à participação no governo Lula. In: AVRITZER, Leonardo (org.). Experiências nacionais de participação social. São Paulo: Cortez, 2009. p. 107-141. 
NATANSON, José. La nueva izquierda. Triunfos y derrotas de los gobiernos de Argentina, Brasil, Bolívia, Venezuela, Chile, Uruguay y Ecuador. Buenos Aires: Debate, 2009.

NAVARRO, Silvio; CABRAL, Maria Clara. Com base recorde em 2007, Lula fracassa no Congresso. Folha de S. Paulo. São Paulo, domingo, 23 de dezembro de 2007. Disponível em: http://www1.folha.uol.com.br/fsp/brasil/fc2312200702.htm. Acesso em: 28 jun. 2016.

NERI, Marcelo Côrtes. A Nova Classe Média: O Lado Brilhante dos Pobres. Rio de Janeiro: FGV/CPS, 2010.

O’DONNELL, Guillermo. Democracia, agência e estado: teoria com intenção comparativa. São Paulo: Paz e Terra, 2011.

OEA - ORGANIZAÇÃO DOS ESTADOS AMERICANOS. Comissão Interamericana de Direitos Humanos. Relatório 2000. RELATÓRIO N 54/01. CASO 12.051. MARIA DA PENHA MAIA FERNANDES. BRASIL. 4 de abril de 2001. Disponível em: https://cidh. oas.org/annualrep/2000port/12051.htm. Acesso em: 07 mar. 2021.

PALOTTI, Pedro Lucas de Moura; CAVALCANTE, Pedro Luiz Costa. Estratégias de Nomeações Ministeriais: entre a política e as políticas públicas. Revista de Sociologia e Política, v. 27, n. 70, 2019.

PANIZZA, Francisco. La marea rosa. Análise de Conjuntura, OPSA, n, 2006.

POGREBINSCHI, Thamy; SAMUELS, David. The Impact of Participatory Democracy: Evidence from Brazil's National Public Policy Conferences. Comparative Politics, v. 46, n³, 2014. p. 313-332.

RIBEIRO, Ednaldo. Voto Compulsório: a desigualdade na participação política. Em Debate, Belo Horizonte, v. 5, n.4, out. 2013, p.41-48.

ROMÃO, Wagner de Melo. Políticas públicas y democracia participativa: avances y límites de las conferencias nacionales en Brasil. In: Minnaert, Anja; Endara, Gustavo. Democracia Participativa e Izquierdas: logros, contradicciones y desafíos. Ecuador: FES-ILDIS, 2015.

SADER, Emir (Org.) 10 anos de governos pós-neoliberais no Brasil: Lula e Dilma. São Paulo, SP: Boitempo: Rio de Janeiro: FLACSO Brasil, 2013.

SANTOS, Boaventura de Sousa; AVRITZER, Leonardo. Introdução: para ampliar o cânone democrático. In: SANTOS, Boaventura de Sousa (Org.). Democratizar a democracia: os caminhos da democracia participativa. Rio de Janeiro: Civilização Brasileira, 2002.

SECRETARIA GERAL DA PRESIDÊNCIA DA REPÚBLICA. Guia dos Conselhos Nacionais. Brasil: Secretaria Nacional de Articulação Social, 2013.

SEN, Amartya. Desenvolvimento como liberdade. São Paulo: Companhia das Letras, 2010. 
SIQUEIRA, Carol. Deputados derrubam decreto dos conselhos populares. Agência Câmara de Notícias. Publicado em 28 de outubro de 2014. Disponível em: https://www.camara.leg. br/noticias/443908-deputados-derrubam-decreto-dos-conselhos-populares/. Acesso em: 07 mar. 2021.

VERBA, Sidney. Political Equality: What is it? Why do we want it? Harvard University: Russell Sage Foundation, 2001. Disponível em: https://www.russellsage.org/sites/all/files/ u4/Verba.pdf. Acesso em: 07 mar. 2021.

VERBA, Sidney; SCHLOZMAN, Kay L.; BRADY, Henry E. Voice and equality: Civic voluntarism in American politics. London: Cambridge University Press, 2005.

ZOVATTO, Daniel. Las instituciones de la democracia directa a nivel nacional en América Latina. Balance comparado: 1978-2010. Revista de Sociología, n²4, 2010. p.87-124.

Recebido em 09/02/2021.

Aprovado em 23/03/2021. 